Journal of Applied Pharmaceutical Science Vol. 7 (05), pp. 051-055, May, 2017

Available online at http://www.japsonline.com

DOI: $10.7324 / J A P S .2017 .70509$

ISSN 2231-3354 (cc) BY-NC-SA

\title{
Screening of in vitro cytotoxic activity of brown seaweeds against hepatocellular carcinoma
}

\author{
Suja Gunasekaran, Vinoth Kumar Thirumalairaj*, Lakshmana Senthil Shanmugasokan, Suganya Pitchai, \\ Rincy Yesudas, Amrutha Chacko \\ Department of Biotechnology, School of Biological Sciences, CMS College of Science and Commerce, Coimbatore, Tamil Nadu, India.
}

\begin{tabular}{|c|c|}
\hline ARTICLE INFO & ABSTRACT \\
\hline Article history: & \multirow{7}{*}{$\begin{array}{l}\text { This study attempts to screen the potential chemotherapeutic agents from three seaweeds extracted with } \\
\text { methanol and tested against hepatocellular carcinoma cells (Hep3B) and normal cell line (Vero). Using MTT } \\
\text { assay, the extracts were checked for their cytotoxicity at six different concentrations. The study exhibited } \\
\text { decrease of the cell viability percentage in dose dependent manner as signified by cell death. Sargassum wightii } \\
\text { extract shows potential cytotoxic activity with } \mathrm{CTC}_{50} \text { of } 10.02 \pm 1.06 \text { and } 180.65 \pm 2.87 \mu \mathrm{g} / \mathrm{ml} \text { against Vero cells } \\
\text { and Hep3B respectively. The methanol fraction led to cell shrinkage, plasma membrane damage and apoptotic } \\
\text { bodies formation showing bioactive components as profound influencing factors for anticancer effects. Further } \\
\text { research need to be explored to purify and characterize the methanol extract to identify the potent therapeutic } \\
\text { tool against liver cancer. }\end{array}$} \\
\hline Received on: 13/11/2016 & \\
\hline Accepted on: 11/01/2017 & \\
\hline Available online: 30/05/2017 & \\
\hline Key words: & \\
\hline Cancer, Seaweeds, & \\
\hline $\begin{array}{l}\text { Sargassum wightii, } \\
\text { Cytotoxicity, MTT assay. }\end{array}$ & \\
\hline
\end{tabular}

\section{INTRODUCTION}

Cancer is still a life threatening disease, despite the development of medical science and modern therapeutic techniques. Cancer had an effect on approximately 10 million people and death rate tends to 5 million per year in developed countries. Lung, breast, stomach, colorectal and liver cancers are most persistent (Jha et al., 2016). Researchers are engaged in the search of active elements from natural products and one such is seaweeds, which have been repeatedly recognized for production of bioactive substances. Cancer has prospered as a major global problem matching its effects in industrializing nations due to their changes in life style and average increase in life span. As per the recent world cancer report, cases of cancer are expected to increase to $50 \%$ i.e. in 2020 it may increases to 15 million (WHO and IARC, 2015).

* Corresponding Author

E. mail: vinothbiochem @ gmail.com
Cancer is indicated by unrestrained cell division, which has the propensity to permeate into other tissues, by growing directly into adjoining tissues via invasion or by getting implanted to far away site by metastasis via circulatory or lymphatic system (Cragg et al., 2005).

Hepatocellular carcinoma (HCC) is the primary malignancy commonly seen in the liver and accounts for as many as 1 million deaths annually worldwide. In certain areas of the world, HCC has the highest recurrence among internal malignancy and hence the customary reason of cancer death (Ali and Gagan, 2014). Although cancer therapy is often rigorous, debilitating and uncomfortable, many people successfully undergo treatment with a minimal disruption of their normal lives.

The development of pristine perspective to improve screening, diagnosis and treatment of cancer is an area of intensive research spending and has generated numerous innovations that have enhanced the rates of continued existence of cancer patients. Natural products with medicinal importance are of prime interest in the research and development of cancer chemotherapeutic drugs. 
The use of natural products for cancer treatment has been increasing owing to its availability, affordability and relatively lesser side effects when compared to the commercially available chemotherapeutic agents (Manosroi et al., 2012; Engel et al., 2011). Marine algae are one among the natural resources in the marine ecosystem. They contain various biologically active compounds which have been used as food source, feed for animals and medicine (Faul Kner, 2000).

By now, around 2400 marine bio-products have been obtained from seaweeds (Manilal et al., 2009). Current findings proved that seaweeds possesses antiviral (Matsuhiro et al., 2005), antibacterial (Xu et al., 2003), and antitumoral potentials (Harada et al., 1997; Kezia et al., 2008) among numerous others.

Marine algae yield a wide range of compounds functioning as chemical defence systems helping in their survival in drastic environments. Algae act as a promising source of bioactive substances that might have pharmaceutical applications due to their biologically active nature (Blunden, 1993).

Animal models have always played a predominant role in both contexts. Although cell culture systems have figured largely in the field of cancer chemotherapy, where the potential value of such systems for cytotoxicity and viability testing is now widely accepted, there is an increase in pressure for a more comprehensive adoption of in vitro analysis in safety evaluation (Harada, 1997).

The present study deals to assess the potency of the crude extracts from marine brown algae against $\mathrm{HCC}$ by in vitro methods and further suggests for the determination and isolation of potent anticancer drug.

\section{METHODOLOGY}

\section{Cell lines and culture conditions}

In this study, two cell lines were used viz., HCC cells (Hep 3B) and normal fibroblast cells (Vero) which were procured from National Centre for Cell Sciences (NCCS), Pune. The cell lines were developed in Minimal Essential Medium (MEM) supplemented with $2 \mathrm{mM}$ glutamine, $1 \mathrm{mM}$ Sodium pyruvate, 0.2 $\mathrm{mM}$ essential aminoacids, $2 \mathrm{~g} / \mathrm{L}$ sodium bicarbonate and $10 \%$ Fetal Bovine Serum (FBS) (Sigma). Humidified condition with $5 \% \mathrm{CO}_{2}$ was used for culturing the cells.

\section{Collection of algae}

Three brown algae Sargassum wightii, Sargassum duplicatum and Sargassum tenerrimum (Authentication number S7/09/2012, S3/09/2012, S8/09/2012, respectively) were collected from Mandapam, Tamil Nadu, India (Lat $9.28^{\circ} \mathrm{N}$, Long $79.12^{\circ} \mathrm{E}$ ). The seaweeds were authenticated by Dr. P. Anantharaman, Associate Professor, Marine Biology, CAS, Chidambaram, Tamil Nadu, India.

\section{Preparation of algal extract}

The collected algae were washed with distilled water and air-dried. The crude extracts were obtained from algae by maceration technique using methanol $(10 \mathrm{~g} / 100 \mathrm{ml})$. The macerated extract was then clarified, filtered and stored at refrigeration condition until use.

\section{Cell viability assay}

To detect the cell viability tryphan blue exclusion test was chosen. A density of $1 \times 10^{6}$ cells/well of cancer and normal cells along with different concentrations of extracts were seeded and incubated at $37^{\circ} \mathrm{C}$ in the presence of $5 \% \mathrm{CO}_{2}$. After $72 \mathrm{hrs}$, $20 \mu \mathrm{l}$ of medium and $0.2 \%$ tryphan blue were mixed, and Neubauer haemocytometer was used to count the live and dead cells (Strober, 1997).

Cell viability $(\%)=$ No of live cells $/$ Total cells $\times 100$

\section{MTT assay}

MTT assay was performed using modified method of Mosmann (1983). Cells were added in 96-well tissue culture plate at a concentration of $1 \times 10^{6}$ cells/well and DMSO was used to prepare the stock solutions of the extracts $(1 \mathrm{mg} / \mathrm{ml})$ and it was then diluted with cell culture medium to obtain the required concentrations $(1000,500,250,125,62.5$ and $31.25 \mu \mathrm{g} / \mathrm{ml})$. Suitable concentrations were added to the cultures and incubated for $72 \mathrm{hrs}$ at $37{ }^{\circ} \mathrm{C}$. Non-treated cells act as control. Incubated cell was then subjected to MTT (3-(4, 5-Dimethylthiazol-2-yl)-2, 5diphenyltetrazolium bromide), and concentration was determined by colorimetric assay. The tetrazolium is used to find out cell viability in assays of cytotoxicity and cell proliferation. In metabolically active cells, an insoluble purple formazon product is formed by the reduction of MTT. An ELISA reader (Bio-Rad® 680 ) was used to read the assay plates at $520 \mathrm{~nm}$. Determination of absorbance and calculation of the corresponding extract concentrations standardizes the cytotoxicity data. The concentration of extract required to kill $50 \%$ of cell population $\left(\mathrm{IC}_{50} / \mathrm{CTC}_{50}\right)$ was determined by plotting a dose-response curve.

$\%$ Growth Inhibition $=(100-[(\mathrm{OD}$ value of Control/ OD values of Test)] $\times 100$ )

\section{Statistical Analysis}

The data point was obtained by making at least 5 independent measurements. The results were expressed as mean \pm SD. Data were analysed by an analysis of variance and $p$ values set as lower than 0.01 were considered as statistically significant by one way ANOVA.

\section{RESULT}

Percentage viability and cell toxic concentration $\left(\mathrm{CTC}_{50}\right)$ was used to express the cytotoxic activity of the crude extracts (Table 1). The rate of viable normal cells at $1000 \mu \mathrm{g} / \mathrm{ml}$ was 80.88 $\pm 3.43 \%$ and the percentage increased up to $99.35 \pm 2.86 \%$ when the extract concentration was diluted to $31.25 \mu \mathrm{g} / \mathrm{ml}$. At higher concentration, $52.26 \pm 0.53 \%$ of viability was observed in cancer cells and the viability increased with decreased concentration. The percentage viability decreases as the concentration increases in 
normal cells. The values are compared with the control and $\mathrm{p}$ value depicts significant result in all concentrations except $1000 \mu \mathrm{g} / \mathrm{ml}$ in Vero cells tested.

Table 1: Cytotoxic study by Tryphan Blue Dye Exclusion Technique in Vero and Hep 3B.

\begin{tabular}{|c|c|c|c|c|}
\hline $\begin{array}{l}\text { S. } \\
\text { No }\end{array}$ & $\begin{array}{c}\text { Name of the } \\
\text { Algae }\end{array}$ & $\begin{array}{c}\text { Concentration } \\
\mu \mathrm{g} / \mathrm{ml}\end{array}$ & $\begin{array}{c}\text { Percentage } \\
\text { viability }(\%)\end{array}$ & \\
\hline & & & Vero cells & Нер 3B \\
\hline \multirow{6}{*}{1.} & \multirow{6}{*}{ S. tenerrimum } & 1000 & $72.05 \pm 0.34$ & $41.82 \pm 1.52$ \\
\hline & & 500 & $87.00 \pm 0.59^{*}$ & $58.33 \pm 0.26$ \\
\hline & & 250 & $89.25 \pm 0.42^{*}$ & $60.78 \pm 1.35$ \\
\hline & & 125 & $92.35 \pm 0.69^{*}$ & $62.35 \pm 0.88$ \\
\hline & & 62.5 & $93.65 \pm 0.71^{*}$ & $66.55 \pm 0.81$ \\
\hline & & 31.25 & $98.50 \pm 0.14^{*}$ & $74.10 \pm 1.28$ \\
\hline \multirow{6}{*}{2.} & \multirow{6}{*}{ S. duplicatum } & 1000 & $76.56 \pm 2.23$ & $44.16 \pm 1.05$ \\
\hline & & 500 & $82.14 \pm 2.97^{*}$ & $51.64 \pm 1.20$ \\
\hline & & 250 & $84.68 \pm 2.47^{*}$ & $62.56 \pm 0.86$ \\
\hline & & 125 & $88.80 \pm 2.32^{*}$ & $70.29 \pm 1.41$ \\
\hline & & 62.5 & $89.10 \pm 2.07^{*}$ & $74.40 \pm 1.54$ \\
\hline & & 31.25 & $91.15 \pm 2.54^{*}$ & $78.34 \pm 1.28$ \\
\hline \multirow{6}{*}{3.} & \multirow{6}{*}{ S. wightii } & 1000 & $80.88 \pm 3.43^{*}$ & $52.26 \pm 0.53$ \\
\hline & & 500 & $85.65 \pm 3.19^{*}$ & $65.62 \pm 0.54$ \\
\hline & & 250 & $88.35 \pm 2.07^{*}$ & $72.69 \pm 1.28^{*}$ \\
\hline & & 125 & $95.25 \pm 1.90^{*}$ & $76.98 \pm 0.98^{*}$ \\
\hline & & 62.5 & $98.92 \pm 1.66^{*}$ & $80.64 \pm 0.73^{*}$ \\
\hline & & 31.25 & $99.35 \pm 2.86^{*}$ & $85.86 \pm 0.41^{*}$ \\
\hline 4. & Cell control & - & 100.00 & 100.00 \\
\hline
\end{tabular}

The results were promising in $S$. wightii methanol extract in all doses with a significant value of $\mathrm{p}<0.01$. In Hep 3B cells concentration less than $250 \mu \mathrm{g} / \mathrm{ml}$ has implicated level of significance with $\mathrm{p}<0.01$ when compared to control. It is observed crude extract of $S$. wightii is influencing the increase in viability in normal Vero cells and decreased viability in cancer cells when compared to that of $S$. tenerrimum and $S$. duplicatum. Depending on the tryphan blue assay, $S$. wightii methanol extract was selected for advanced studies to determine viability.

Table 2: Result of viability test for Hep 3B cell line of S. wightii.

\begin{tabular}{cccc}
\hline $\begin{array}{c}\text { S. } \\
\text { No }\end{array}$ & $\begin{array}{c}\text { Extract concentration } \\
(\boldsymbol{\mu g} / \mathbf{m l})\end{array}$ & No of dead cells & $\begin{array}{c}\text { No of viable } \\
\text { cells }\end{array}$ \\
\hline 1. & 1000 & $1.8 \times 10^{6}$ & $1.4 \times 10^{6}$ \\
2. & 500 & $1.5 \times 10^{6}$ & $1.8 \times 10^{6}$ \\
3. & 250 & $0.82 \times 10^{6}$ & $2.0 \times 10^{6}$ \\
4. & 125 & $0.41 \times 10^{6}$ & $2.2 \times 10^{6}$ \\
5. & 625 & $0.26 \times 10^{6}$ & $2.3 \times 10^{6}$ \\
6. & 31.25 & $0.21 \times 10^{6}$ & $2.4 \times 10^{6}$ \\
7. & 15.625 & $0.18 \times 10^{6}$ & $2.56 \times 10^{6}$ \\
8. & 7.81 & $0.15 \times 10^{6}$ & $2.6 \times 10^{6}$ \\
9. & 3.90 & $0.14 \times 10^{6}$ & $2.72 \times 10^{6}$ \\
10. & 1.95 & $0.12 \times 10^{6}$ & $2.75 \times 10^{6}$ \\
11. & 0.97 & $0.10 \times 10^{6}$ & $2.77 \times 10^{6}$ \\
12. & 0.48 & $0.08 \times 10^{6}$ & $2.82 \times 10^{6}$ \\
\hline
\end{tabular}

In Table 2 one negative control and 11 concentrations of the sample were tested against liver cancer cells Hep 3B. Tryphan blue was added to count the viable and non-viable cells. In negative control, the number of non-viable cells is comparably less and the cell count increased from up to $1.8 \times 10^{6}$ after 72 hours of incubation. Increase in extract concentration enhanced the viable and non-viable cells. Concentrations up to $125 \mu \mathrm{g} / \mathrm{ml}$ showed raise in viable cells and decrease in dead cell count. The reduction in the number of viable cells started from the effectual concentration of $250 \mu \mathrm{g} / \mathrm{ml}$. When compared with negative control the initial concentrations of extracts didn't possess anticancer activity against the liver cancer cell line (Table 3).

Table 3: Cytotoxicity Study of $S$. wightii methanol extract by MTT assay In Vero and Hep 3B cell lines.

\begin{tabular}{|c|c|c|c|c|}
\hline S. No & Cell line & Concentrations & $\begin{array}{l}\text { \% Growth } \\
\text { Inhibition }\end{array}$ & $\begin{array}{c}\text { CTC }_{50} \text { value } \\
(\mu \mathrm{g} / \mathrm{ml})\end{array}$ \\
\hline 1. & 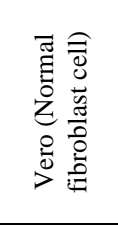 & $\begin{array}{c}1000 \mu \mathrm{g} / \mathrm{ml} \\
500 \mu \mathrm{g} / \mathrm{ml} \\
250 \mu \mathrm{g} / \mathrm{ml} \\
125 \mu \mathrm{g} / \mathrm{ml} \\
62 \mu \mathrm{g} / \mathrm{ml} \\
31 \mu \mathrm{g} / \mathrm{ml} \\
15 \mu \mathrm{g} / \mathrm{ml}\end{array}$ & $\begin{array}{l}15.20 \pm 0.25 \\
13.11 \pm 0.56 \\
12.75 \pm 0.29 \\
10.65 \pm 0.57 \\
10.25 \pm 0.85 \\
10.09 \pm 0.68 \\
10.05 \pm 0.41\end{array}$ & $10.02 \pm 1.06$ \\
\hline 2. & 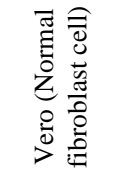 & Control & 0.00 & - \\
\hline 3. & 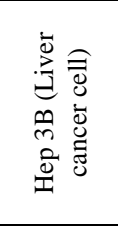 & $\begin{array}{c}1000 \mu \mathrm{g} / \mathrm{ml} \\
500 \mu \mathrm{g} / \mathrm{ml} \\
250 \mu \mathrm{g} / \mathrm{ml} \\
125 \mu \mathrm{g} / \mathrm{ml} \\
62 \mu \mathrm{g} / \mathrm{ml} \\
31 \mu \mathrm{g} / \mathrm{ml} \\
15 \mu \mathrm{g} / \mathrm{ml}\end{array}$ & $\begin{array}{l}88.32 \pm 1.56 \\
74.68 \pm 1.40 \\
70.22 \pm 1.84 \\
66.91 \pm 1.05 \\
65.87 \pm 1.81 \\
65.66 \pm 1.52 \\
65.65 \pm 1.06\end{array}$ & $180.65 \pm 2.87^{* *}$ \\
\hline 4. & 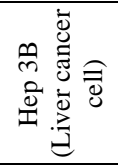 & $\begin{array}{c}\text { Standard - } \\
\text { Cisplatin } 100 \\
\mu \mathrm{g} / \mathrm{ml} \\
50 \mu \mathrm{g} / \mathrm{ml} \\
25 \mu \mathrm{g} / \mathrm{ml}\end{array}$ & $\begin{array}{c}100 \\
95.25 \pm 0.65 \\
90.25 \pm 0.58\end{array}$ & $28.25 \pm 1.02^{* *}$ \\
\hline
\end{tabular}

MTT assay an accessible, non-radioactive alternative method is relevant in determining the cell proliferation and cytotoxic concentration. The Vero cells assayed with $S$. wightii extract has imparted $15.20 \pm 0.25$ to $10.05 \pm 0.41 \%$ growth inhibition with decrease in concentration and $\mathrm{CTC}_{50}$ of $10.02 \pm$ 1.06. In liver cancer cells it is evident at elevated dose was $88.32 \pm$ $1.56 \%$ inhibition and decreased with decrease in concentration up to $62.5 \mu \mathrm{g} / \mathrm{ml}$ and further lower doses maintained a constant percentage inhibition. Hepatocellular carcinoma cells cells were compared with standard silymarin at three doses with $\mathrm{CTC}_{50}$ of $28.25 \pm 1.02$ and statically significant with $\mathrm{p}$ value and $\mathrm{CTC}_{50}$ $180.65 \pm 2.87$.

Methanol extract of S. wightii showed $100 \%$ cytotoxicity to Hep3B cells (Figure 1) and control showed no cytotoxicity (Figure 2). For Vero cells, methanol extract of $S$. wightii showed less cytotoxicity (Figure 3 ) and no cytotoxicity was observed in control (Figure 4). Comparable with the other seaweeds extracts taken in the present study, $S$. wightii is considered potent against cancer cells and less toxic to normal cells. 


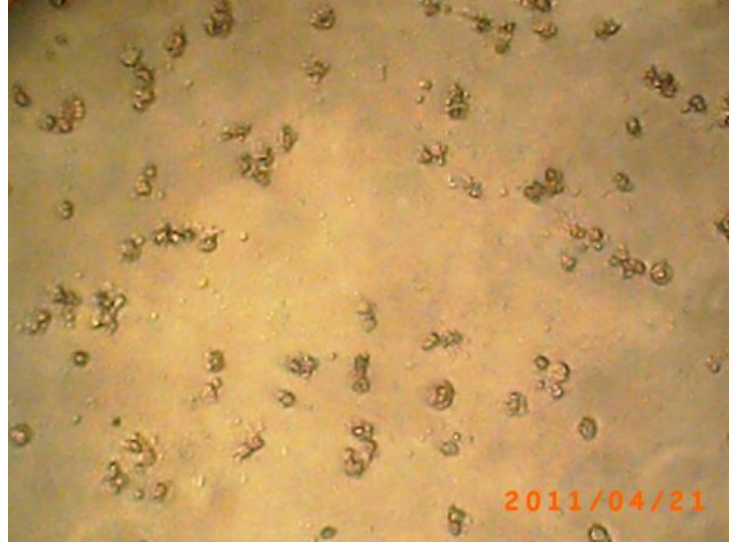

Fig. 1: Cytotoxicity effect of methanol extract of $S$. wightii to Hep3B cells.

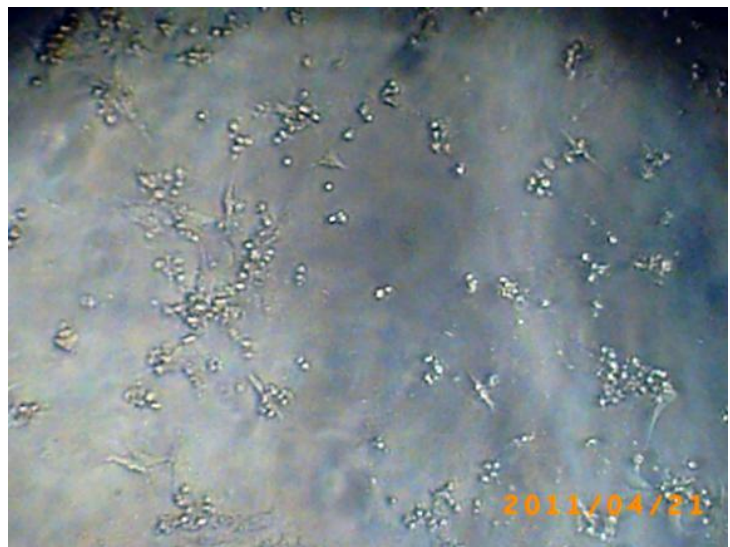

Fig. 3: Less cytotoxicity effect of methanol extract of $S$. wightii to Vero cells.

\section{DISCUSSION}

Cancer has a great infliction on the human population for many decades even though several approaches have been in prevention, diagnosis and treatment of the disease. Most of the existing anticancer drugs are toxic to normal cells and causes side effects at various circumstances. The discovery and establishment of a distinct anticancer agent with low side effect and toxicity has become a requisite goal. With this aim, researchers have been concentrating on the discovery of potent novel compounds derived from natural resources with anticancer activity.

The process of drug discovery includes preclinical assessment of large number of drugs for specific and non-specific cytotoxicity against different cells. To screen potential anticancer agents, in vitro assays have been a common practice almost since the beginning of cancer chemotherapy in 1946. Natural products have a significant role in cancer therapy today.

These extensive numbers of anticancer agents are either natural (from plants, animals and microorganisms) or their derivatives (Stefania et al., 2009). The elevated toxicity of some cancer chemotherapy drugs and their detrimental side effects increase the need for new anti-tumour drugs against incurable tumours (Arnold, 2011). Seaweeds are one among the natural resources in the marine ecosystem that contains numerous

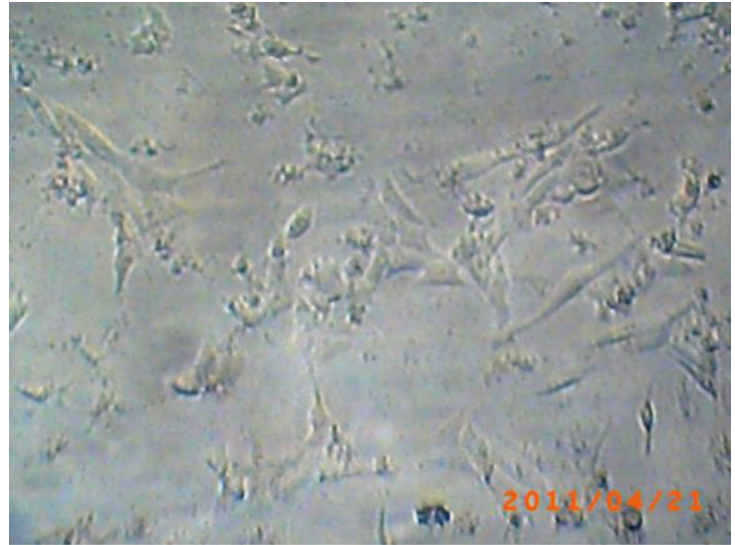

Fig. 2: Control Hep3B cells.

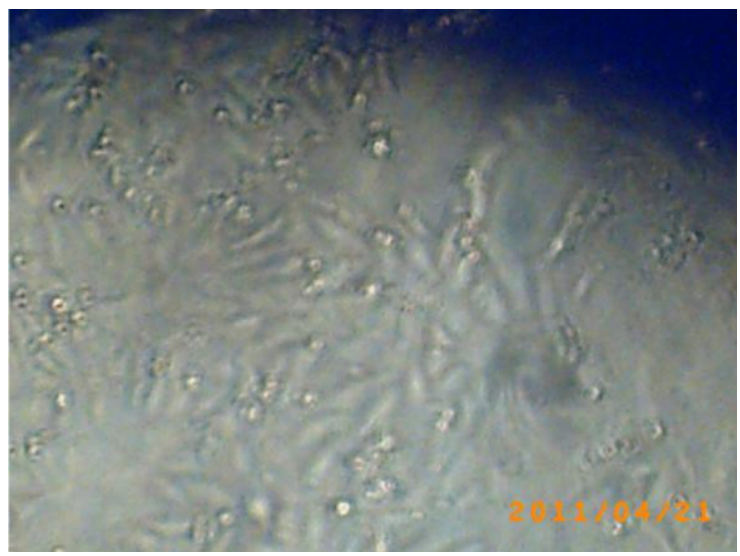

Fig. 4: Control Vero cells.

biologically active compounds that have been used as a source of food and medicine. Marine seaweeds have been recognized as unique for its structural and functional components when compared to terrestrial organisms. In the progression of natural product drug discovery, it is mandatory to determine the potential of cytotoxicity against human cancer cell lines. The agents which display specific activity on cell lines are recommended for in vivo studies. Therefore, it is necessary to screen the agents discovered with the common methods like tryphan blue and MTT assay.

Researchers have reported that colorectal cancer can be effectively treated with marine natural products, which focus ample of biologically active compounds with favourable pharmacological activities (Rye et al., 2013). This study was aimed to assess the cytotoxicity of three different seaweeds methanol extracts against Hep3B and Vero cell lines by tryphan blue and MTT assay.

It is observed in the earlier reports ethanol extract of $S$. wightii contains novel polysaccharide which exhibited anti proliferative activity against AGS, HeLa, MCF 7 and PC 12 cell lines. Anti cancer activity in aqueous extract of $S$. oligocystum has proved its effectiveness for treating cancer cell lines, Daudi and K562 with an $\mathrm{IC}_{50}$ value of 500 and $400 \mu \mathrm{g} / \mathrm{ml}$ (Faulkner, 2000). The compounds isolated from Sargassum $s p$. are invariably having 
pesticidal, antihelmentic, antifungal, antimicrobial, antioxidant, insect repellent, nematicidal and cancer preventive properties (Bluden, 1993). The present study infers that $S$. wightii has potential in inhibiting liver cancer cells. In Vero cells at higher concentration, the viability percentage was moderate and decrease in concentration has increased viability as the toxic level in crude in more at higher concentration. This implies increase in concentration has started inhibiting the normal cells.

Concentration below $500 \mu \mathrm{g} / \mathrm{ml}$ has showed drastic decrease in two fold in dead cells. The ranges between $500 \mu \mathrm{g} / \mathrm{ml}$ to $250 \mu \mathrm{g} / \mathrm{ml}$ have clearly determined the $\mathrm{CTC}_{50}$ value as $180.65 \pm 2.87 \mu \mathrm{g} / \mathrm{ml}$ for cancer cells and $10.02 \pm 1.06 \mu \mathrm{g} / \mathrm{ml}$ for normal cells. The methanol extract has induced cell contraction when observed morphologically and evidence the presence of cytotoxic effect. This extract showed comparatively higher regenerative capacity, which is measured with reference to plating efficiency in Vero cell culture, compared to the cancer cells, indicating its affinity to cancer cells. In marine algae, the anticancer activity is one of the essential activities and the cytotoxic properties of the species belong to four structural types (Mayer et al., 2003). It was revealed that sulfur-containing compounds such as fuciodans extracted from Sargassum polycystum and other brown algae exhibited important roles against some human carcinoma cells (Ly et al., 2005). Random screening is effective to have found different marine algae with anti tumour activities. Sargassum fusiforme has a discriminatory human cancer cytotoxin and significant activity against Ehrlich carcinoma cells (Ogawa et al., 2004). The present work is supported in context with many researchers.

\section{CONCLUSION}

A crude natural product extract is in general highly complicated blend of numerous compounds possessing variable chemico physical properties habitually with opposing pharmaceutical properties and removing the compounds might increase the toxic effect on cancer cells and meanwhile no toxicity for normal cells. It is interesting that among the screened one seaweed $S$. wightii methanol extract exhibits effective anticancer activity and seems to have low toxicity on normal cells. Further investigations are required to isolate, characterize and identify the lead compound and it can be implicated as an effective therapeutic tool against liver cancer.

\section{ACKNOWLEDGEMENT}

The authors are obliged to the authorities of CMS college of Science and Commerce for the facilities.

Financial support and sponsorship: Nil.

Conflict of Interests: The authors' declare no conflict of interest.

\section{REFERENCES}

Ali R, Gagam KS. Hepatocellular carcinoma review: Current treatment and evidence- based medicines. World J gastroentero,
$2015 ; 4115-4127$.

American Cancer Society. Cancer Facts and Figures. 2010,4 5-

46.

Archana S, Samit G, Shamee. Allium vegetables in cancer prevention: An overview. Asian pac J Cancer Prev, 2004; 5: 237- 245.

Arnold LD, Preeti V. Natural products for cancer chemotherapy. Micros biotechnol, 2011; 4(6): 687-699.

Blunden G. Marine algae as sources of biologically active compounds. Interdiscip Sci Rev, 1993; 18: 73-80.

Cragg GM, Newman DJ. Plants as a source of anti- cancer agents. J Ethnopharmacol, 2005; 100: 72-79.

Engel N, Oppermanne C, Falodunb A, Kragle U. Proliferative effects of five traditional Nigerian medicinal plant extracts on human breast and bone cancer cell lines. J Ethnopharmacol, 2011; 137(2): 1003 1010 .

7- 55

Faulkner DJ. Marine natural products. Nat Prod Rep, 2000; 17:

Harada H, Noro T, Kamei Y. Selective antitumor activity in vitro from marine algae from Japan coast. Biol Pharm Bull, 1997; 20: 541 546.

Jha P, Chaloupka FJ, Corrao M, Jacob B. Reducing the burden of smoking world-wide: effectiveness of interventions and their coverage. Drug Alcohol Rev, 2006; 25(6): 597-609.

Lye BM, Buu NQ, Nhut ND, Thinh PD, Thi T, Van T. Studies on fucoidan and its production from Vietnamese brown sea weeds. AJSTD, 2005; 22: 371-380.

Manosroi J, Sainakham M, Manosroi W, Manosroi A. Antiproliferative and apoptosis induction activities of extract from Thai medicinal plant recipes selected from MANOSROI II database. J Ethnopharmacol, 2012; 141(1): 451-459.

Manilal A, Sujith S, Kiran GS, Selvin J, Shikar C. Cytotoxic potentials of red algae, Laurencia brandenii collected from the Indian Coast. Global J Pharmacol, 2009; 3: 90-94.

Matsuhiro B, Conte AF, Damonte EB, Kolender AA, Matulewicz MC, Mejias EG, Pujol CA, Zuniga EA. Structural analysis and antiviral activity of a sulphated galactan from the red seaweed Schizymenia binderi (Gigartinales Rhodophyta). Carbohydr Res, 2005; 340: 2392- 2402.

Mayer AMS, Gustafson KR. Marine pharmacology in 2000: Antitumour and cytotoxic compounds. Int J Cancer, 2003; 105: 291-299.

Mosmann T. Rapid colorimetric assay for cellular growth and survival: application to proliferation and cytotoxicity assays. J Immunol Methods, 1983; 65: 55-63.

Ryu MJ, KimAD, Kang KA, Chung HS, KimHS, Suh IS, Chang WY, Hyun JW. The green algae Ulva fasciata Delile extract induces apoptotic cell death in human colon cancer cells. In vitro Cell Dev Bio Anim, 2013; 49: 74-81.

Stefania N, Donatella L, Ewa W, Martino D, Letizia B, Enrico M, Sergio. Natural compounds for cáncer treatment and prevention. Pharmacol Res, 2009; 59: 365-378.

Strober W. Tryphan blue exclusion test of cell viability. Curr Protoc Immunol, 1997; A3.B.1- A3.B.2

WHO and IARC (2015) IARC Biennial Report of 2014-2015.

Xu N, Fan X, Yan XJ, Li X, Niu R, Tseng CK. Antibacterial bromophenols from the marine red algae Rhodomela confervoides. Phytochemistry, 2013; 62: 1221- 1224.

\section{How to cite this article:}

Suja G, Vinothkumar T, Lakshmanasenthil S, Yesudas R, Chacko A, Suganya P. Screening of in vitro cytotoxic activity of brown seaweeds against hepatocellular carcinoma. J App Pharm Sci, 2017; 7 (05): 051-055. 